\title{
Relevance of Microstructure on Optical Properties of Thermally Evaporated Indium Oxide Thin Films
}

\author{
Parveen Jain 1,2, Sukhvir Singh1", Avanish Kumar Srivastava1, Sandeep Kumar Pundir1, \\ Azher Majid Siddiqui ${ }^{2}$ \\ ${ }^{1}$ CSIR-National Physical laboratory, New Delhi, India \\ 2Jamia Millia Islamia, New Delhi, India \\ Email: sukhvirster@gmail.com
}

Received 12 November 2014; accepted 27 December 2014; published 15 January 2015

Copyright (C) 2015 by authors and OALib.

This work is licensed under the Creative Commons Attribution International License (CC BY). http://creativecommons.org/licenses/by/4.0/

(c) (i) Open Access

\begin{abstract}
Nanocrystalline indium oxide thin films of thickness about $100 \mathrm{~nm}$ have been deposited using thermal vacuum evaporation technique at room temperature on glass and quartz substrates and subsequently annealed at different temperatures $\left(150^{\circ} \mathrm{C}, 200^{\circ} \mathrm{C}, 250^{\circ} \mathrm{C}, 300^{\circ} \mathrm{C}, 350^{\circ} \mathrm{C}, 500^{\circ} \mathrm{C}\right.$ and $\left.700^{\circ} \mathrm{C}\right)$ for $2 \mathrm{hr}$ and $4 \mathrm{hr}$ in the oxygen atmosphere. Structural and optical properties of these films have been investigated by using XRD, SEM, HRTEM, AFM, UV-Visible, and photoluminescence spectroscopy. Response of gas towards the thin films is obtained. X-ray diffraction studies of the as deposited and annealed films show the transformation of indium into indium oxide thin films at $300^{\circ} \mathrm{C}$. UV-visible and PL studies reveal the band gap of $3.7 \mathrm{eV}$. The transparency of thin films is about 83\%. Gas response is obtained 3.55 for ethanol vapours. Structural features associated with the indium oxide thin films have been correlated with optical parameters.
\end{abstract}

\section{Keywords}

Vacuum Evaporation, Photoluminescence, UV-Visible, Gas Sensing

Subject Areas: Industrial Engineering, Nanometer Materials

\section{Introduction}

Indium Oxide $\left(\mathrm{In}_{2} \mathrm{O}_{3}\right)$ is an amphoteric oxide of Indium (In) which has a melting point $1910^{\circ} \mathrm{C}$. Its density is $7.179 \mathrm{~g} / \mathrm{cm}^{3}$ and appears as yellowish green odorless crystals. Amorphous indium oxide is insoluble in water but soluble in acids, whereas crystalline indium oxide is insoluble in both water and acids. The crystalline form ex-

"Corresponding author.

How to cite this paper: Jain, P., Singh, S., Srivastava, A.K., Pundir, S.K. and Siddiqui, A.M. (2015) Relevance of Microstructure on Optical Properties of Thermally Evaporated Indium Oxide Thin Films. Open Access Library Journal, 2: e1200.

http://dx.doi.org/10.4236/oalib.1101200 
ists in the cubic phase having lattice parameter $10.11 \AA$. It is n-type semiconductor with a direct band gap (3.5 $3.7 \mathrm{eV}$ ) [1], which has low resistivity. In recent years, lower-dimensional semiconductor nanostructures, such as nanowires, nanorods and nanobelts of several binary oxide systems, including $\mathrm{ZnO}, \mathrm{SnO}_{2}, \mathrm{In}_{2} \mathrm{O}_{3}$ and $\mathrm{GeO}_{2}$ [5]-[10], have been intensively investigated because of their novel properties (optical, electrical, and magnetic properties) and their potential applications in nano-devices. Among them, the $\operatorname{In}_{2} \mathrm{O}_{3}$, which is a wide band gap transparent semiconductor material, has been widely used in the microelectronic applications including window heaters, solar cells, and liquid-crystal displays [2]-[4]. The production and properties of transparent conducting oxide (TCO) thin films such as indium oxide, tin oxide and indium tin oxide have been extensively studied, since the films were used in a variety of applications. Among the most important are solar cells, flat panel displays, UV lasers and detectors, photoelectrode materials, and films as gas sensor [5] [6]. At $300^{\circ} \mathrm{C}$ the indium oxide films exhibit a very high response (99\%) to methanol vapor at a concentration of $40 \mathrm{ppm}$ in air, which is ideal to be used as a methanol sensor [7].

Indium Oxide films have been synthesized by various deposition techniques, such as direct current (DC) magnetron sputtering, reactive thermal evaporation, ion beam sputtering and chemical vapor deposition (CVD) [8]-[10]. Post deposition annealing is often employed to improve or change the features of such films. There are only a few studies on $\operatorname{In}_{2} \mathrm{O}_{3}$ films prepared by thermal oxidation of metallic Indium films. Indium oxide films prepared by the oxidation of Indium films at $500^{\circ} \mathrm{C}$ in the presence of air show high electrical conductivity, lower band gaps $(2.4-2.8 \mathrm{eV})$ and low transmission $(\sim 40 \%)$ [11]. Indium oxide films prepared in the temperature range of $500^{\circ} \mathrm{C}-900^{\circ} \mathrm{C}$ show orange photoluminescence [12]. Authors attribute this phenomenon to the presence of defects or oxygen deficiencies in the films. However, these studies do not explain in detail the compositional and morphological features which have strong relevance with the electrical and optical properties of the films.

The present study deals with investigations on the annealing of In metallic films in the presence of oxygen atmosphere in $150^{\circ} \mathrm{C}-700^{\circ} \mathrm{C}$ temperature range for $2 \mathrm{hr}$ on glass and quartz substrates. $100 \mathrm{~nm}$ thin films are grown by thermal evaporation of Indium metal. Structural and optical properties of these films have been investigated by using XRD, SEM, TEM, AFM, UV-Visible, and photoluminescence spectroscopy. X-ray diffraction studies of the as deposited and annealed films show the transformation of indium into indium oxide thin films at $300^{\circ} \mathrm{C}$. This study further elaborates a bright illustration of the influence of morphology on the oxidation behavior of Indium films.

\section{Experimental Details}

\subsection{Synthesis}

Indium oxide thin films were prepared by thermal evaporation method under vacuum conditions using high purity indium (in $99.999 \%$ pure) as the source material. The pure element was procured from M/s Alfa Aesar. The thickness of the thin films was kept around $\sim 100 \mathrm{~nm}$. Thin films of indium were deposited at room temperature under vacuum of the order of $10^{-5} \mathrm{mbar}$. As deposited films, on glass and quartz substrates, were annealed at different temperatures $\left(150^{\circ} \mathrm{C}, 200^{\circ} \mathrm{C}, 250^{\circ} \mathrm{C}, 300^{\circ} \mathrm{C}, 350^{\circ} \mathrm{C}, 500^{\circ} \mathrm{C}\right.$ and $\left.700^{\circ} \mathrm{C}\right)$ for $2 \mathrm{hr}$ and $4 \mathrm{hr}$ under high purity oxygen gas atmosphere in order to synthesize good quality single phase indium oxide films. The experimental details are summarized in the Table 1.

\subsection{Characterization}

The detailed study on XRD measurements were carried out on as deposited as well as on annealed films at different temperatures under $\mathrm{O}_{2}$ atmosphere to identify the phase of the indium oxide thin films by using x-ray diffractometer model Bruker Axes using $\mathrm{CuK}_{\alpha}$ radiations $(\lambda=1.54178 \AA)$. Photoluminescence spectra were recorded by using a PL spectrometer model Perkin Elmer LS 55 for the investigation of photoluminescence properties at the excitation wave length of $274 \mathrm{~nm}$. The UV-visible spectra were taken by using UV-visible spectrometer model Hitachi U3900H in the UV-visible range between $200 \mathrm{~nm}$ to $900 \mathrm{~nm}$. Thin films were examined for surface morphology by SEM (Model: Leo EVOMA10). AFM scans were performed using a multimode V, make Veeco instrument in contact mode with NP20 tips. The films deposited onto KBr substrate were used for the microstructural investigations under high resolution transmission electron microscope (HRTEM) model Tecani G2F30 STWIN. The acceleration voltage was $300 \mathrm{kV}$. A systematic synthesis process has been shown in Figure 1(a) and Figure 1(b) to explain the transparency achieved while annealing the as deposited indium thin film at 
Table 1. Detailed comparisons of indium oxide thin films; crystalline phases, crystallite size according to the annealing conditions.

\begin{tabular}{ccccccc}
\hline S. No. & Temperature & Time $(\mathbf{h r})$ & Phase & Lattice Parameter $(\AA)$ & Volume of Unit Cell $\left(\AA^{3}\right)$ & Crystallite Size $(\mathbf{n m})$ \\
\hline 1. & As deposited (glass) & - & Tetragonal & $\mathrm{a}=3.241, \mathrm{c}=4.933$ & 64.58 & 67 \\
2. & $150^{\circ} \mathrm{C}$ (glass) & 2 & Tetragonal & $\mathrm{a}=3.241, \mathrm{c}=4.925$ & 51.73 & 65 \\
3. & $200^{\circ} \mathrm{C}$ (glass) & 2 & Tetragonal & $\mathrm{a}=3.241, \mathrm{c}=4.925$ & 51.73 & 68 \\
4. & $250^{\circ} \mathrm{C}$ (glass) & 2 & Tetragonal & $\mathrm{a}=3.241, \mathrm{c}=4.926$ & 51.743 & 66 \\
5. & $300^{\circ} \mathrm{C}$ (glass) & 2 & Cubic & 10.009 & 1002.90 & 28 \\
6. & $350^{\circ} \mathrm{C}$ (glass) & 2 & Cubic & 10.062 & 1018.71 & 36 \\
7. & $\mathrm{As} \mathrm{deposited} \mathrm{(quartz)}$ & - & Tetragonal & $\mathrm{a}=3.234, \mathrm{c}=4.912$ & 51.37 & 46 \\
8. & $300^{\circ} \mathrm{C}$ (quartz) & 4 & Cubic & 10.008 & 1002.40 & 23 \\
9. & $500^{\circ} \mathrm{C}$ (quartz) & 4 & Cubic & 9.971 & 991.60 & 22 \\
10. & $700^{\circ} \mathrm{C}$ (quartz) & 4 & Cubic & 10.045 & 1013.61 & 38 \\
\hline
\end{tabular}

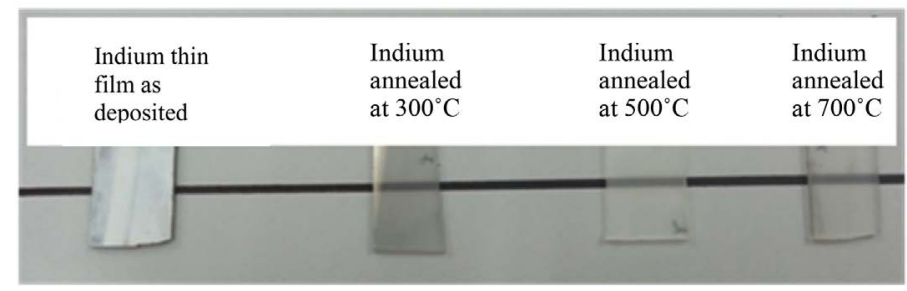

(a)

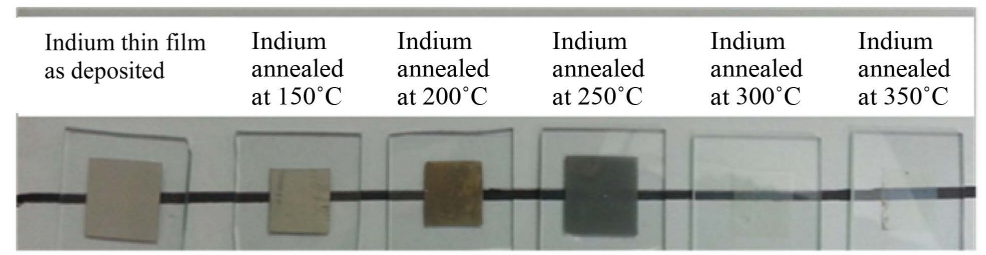

(b)

Figure 1. (a) Thin films of indium annealed at different temperatures on quartz substrate for $4 \mathrm{hr}$; (b) Thin films of indium annealed at different temperatures on glass substrate for $2 \mathrm{hr}$.

different temperatures under $\mathrm{O}_{2}$ atmosphere for different time periods. In these figures, the visibility of background black line depicts the transparency of thin films. It is evident that indium thin film annealed at higher temperature revealed the highest transparency.

\section{Results \& Discussions}

\subsection{Phase Formation}

The structure and crystalline orientation of indium oxide thin films deposited on the glass substrates were determined by XRD analysis. The XRD pattern of indium film deposited at RT as shown in Figure 2(a) reveals the single phase of indium. However as we annealed these thin films at $150^{\circ} \mathrm{C}, 200^{\circ} \mathrm{C}$ and $250^{\circ} \mathrm{C}$ as shown in Figures 2(b)-(d), the mixed phase of $\mathrm{In}$ and $\mathrm{In}_{2} \mathrm{O}_{3}$ are observed. The reflections of $\left(\begin{array}{lll}1 & 0 & 1\end{array}\right),\left(\begin{array}{lll}0 & 0 & 2\end{array}\right)$ and $\left(\begin{array}{lll}2 & 0 & 2\end{array}\right)$ planes correspond to indium. But a reflection from $\left(\begin{array}{lll}2 & 2 & 2\end{array}\right)$ plane corresponding to $\operatorname{In}_{2} \mathrm{O}_{3}$ is also observed in films annealed at 150,200 and $250^{\circ} \mathrm{C}$. All the reflections are matched from JCPDF card no. 85-1409 for indium and card no. 44-1087 for indium oxide $\left(\operatorname{In}_{2} \mathrm{O}_{3}\right)$. This reveals that the formation of indium oxide from indium get started but not completely synthesized into single phase of indium oxide. 


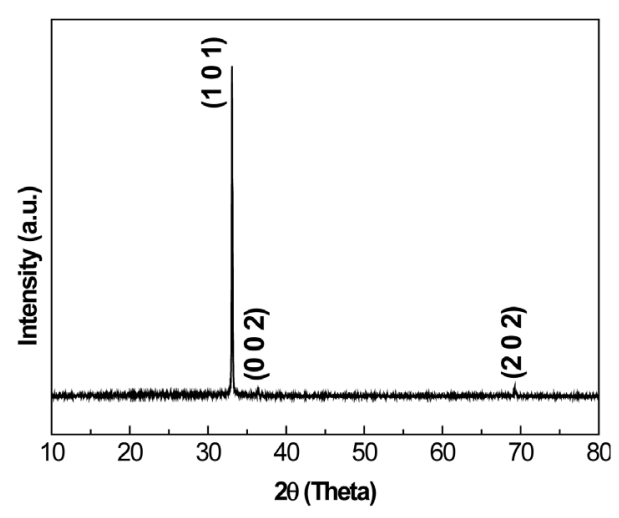

(a)

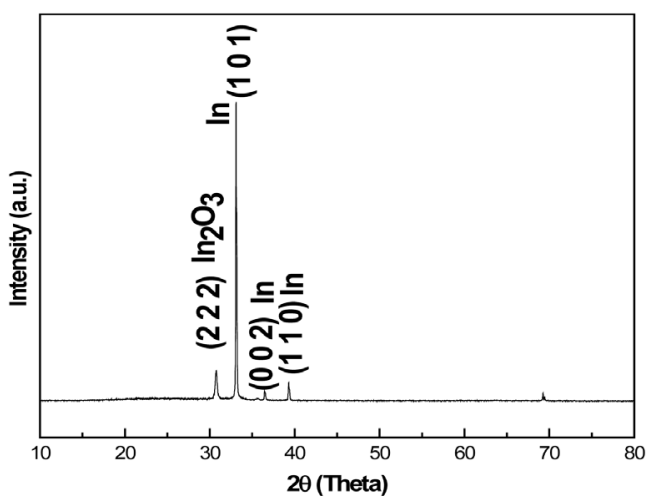

(c)

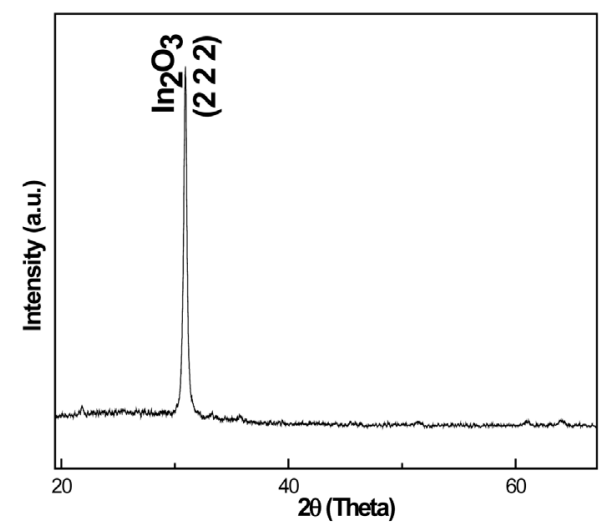

(e)

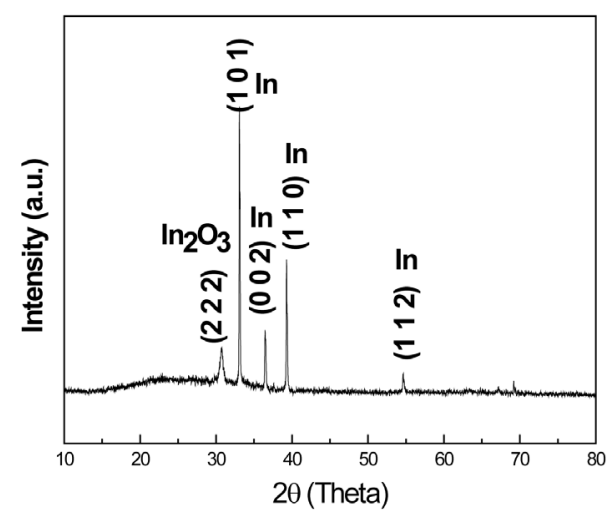

(b)

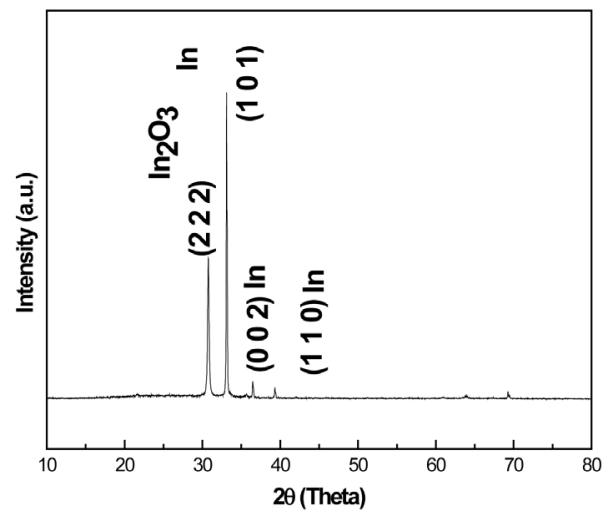

(d)

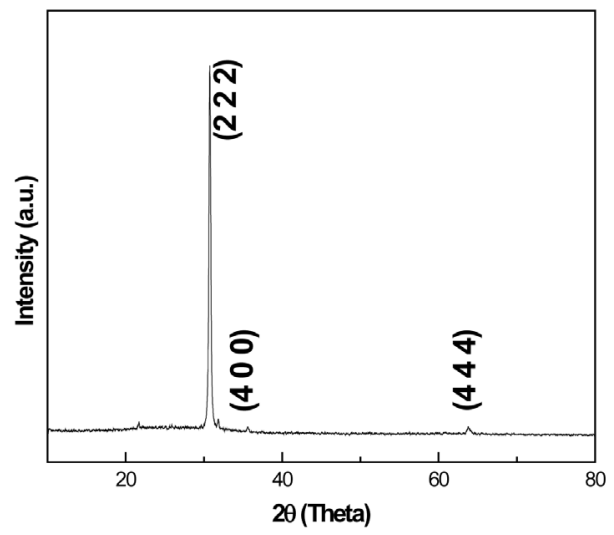

(f)

Figure 2. XRD Patterns for the indium as deposited thin films and annealed at $150^{\circ} \mathrm{C}, 200^{\circ} \mathrm{C}, 250^{\circ} \mathrm{C}$, $300^{\circ} \mathrm{C}$ and $350^{\circ} \mathrm{C}$ on glass substrate.

The XRD patterns of thin films annealed at 300 and $350^{\circ} \mathrm{C}$ are shown in Figure 2(e) and Figure 2(f). These patterns reveal the formation of $\operatorname{In}_{2} \mathrm{O}_{3}$ phase of cubic structure having reflections from (2 22 2), ( $\left.\begin{array}{lll}4 & 0 & 0\end{array}\right)$ and (4 4 4) planes. These reflections are compared with JCPDF card No. 44-1087 and found with good agreement.

On analysis of the XRD pattern, as shown in Figure 3(a), shows that even on quartz substrate, the thin films of indium oxide annealed at $300^{\circ} \mathrm{C}, 500^{\circ} \mathrm{C}$ and $700^{\circ} \mathrm{C}$ revealed single phase of $\operatorname{In}_{2} \mathrm{O}_{3}$ having cubic structure. When annealed at $700^{\circ} \mathrm{C}$ it is observed from XRD pattern that highly oriented growth has taken place along $\left(\begin{array}{lll}2 & 2 & 2\end{array}\right)$ plane of indium oxide (JCPDF No. 44-1087). The crystallite size is found to be increased with the increase of annealing temperature as shown in Table 1 . This means that after the formation of single phase of indium oxide at $300^{\circ} \mathrm{C}$, the annealing temperature plays an important role for the increase of crystallite size of indium oxide thin 
films. After annealing the as deposited films, tetragonal structure of indium gets changed into cubical structure of indium oxide, which is understandable because the lower symmetry crystals (tetragonal) is transformed to higher symmetry cubic crystals. For better visualization, schematic of tetragonal and cubic unit cells, as per the respective dimensional proportionate, are depicted in Figure 3(b).

\subsection{Morphology and Microstructure}

Surface morphology of the as deposited and annealed films at $150^{\circ} \mathrm{C}, 200^{\circ} \mathrm{C}, 250^{\circ} \mathrm{C}, 300^{\circ} \mathrm{C}$ and $350^{\circ} \mathrm{C}$ films of indium oxide were carried out using Scanning Electron Microscope (SEM). After studying the SEM images we can observe that as deposited thin film of In shows the presence of very small particles in the form of granules having size between $250 \mathrm{~nm}$ to $1 \mu \mathrm{m}$. The shapes of these particles are not uniform as depicted in the SEM micrograph Figure 4(a). Thin films Annealed at $150^{\circ} \mathrm{C}$ temperature results in growth of elongated particles distributed uniformly in different directions revealing increase in particle size as depicted in Figure 4(b). Further annealing at higher temperatures $\left(200^{\circ} \mathrm{C}\right.$ and $\left.250^{\circ} \mathrm{C}\right)$ leads to Wetting effect as observed in SEM micrograph shown Figure 4(c) and Figure 4(d), since the melting temperature of In is $156^{\circ} \mathrm{C}$. At some places localized growth of particles are also observed with some unusual features. After annealing at $300^{\circ} \mathrm{C}$ for $2 \mathrm{hrs}$ it is observed that the film has become uniform with the presence of some very fine particles throughout the film. The growth of very fine indium oxide particles on the surface of the film may be due to re-crystallization which has taken place at this annealing temperature. After annealing of thin film at $350^{\circ} \mathrm{C}$, stress is developed in the films because of the difference in linear thermal co-efficient of glass and indium oxide thin films as depicted in the Figure 4(f). However the particle size is found to be increased in the thin film.

To optimize the conditions of synthesis of $\operatorname{In}_{2} \mathrm{O}_{3}$ thin films, the indium films were also deposited on quartz substrate instead of glass because it can withstand at high temperature on quartz (melting point $\sim 1670^{\circ} \mathrm{C}$ ) as compared to the glass $\left(\sim 400^{\circ} \mathrm{C}\right)$. As the melting point of indium oxide is $1910^{\circ} \mathrm{C}$ which is close to the melting point of quartz. This is the reason for not observing thermal stress in films deposited on quartz substrates and annealed at higher temperatures. The SEM images of as deposited films and annealed at 300,500 and $700^{\circ} \mathrm{C}$ for $4 \mathrm{hr}$ on quartz substrate are shown in Figures 5(a)-(d). The SEM images of as deposited thin films recorded at $20 \mathrm{kX}$ magnification show that the thin films are of uniform nature having granular shape particles of size varying between $500 \mathrm{~nm}$ to $1 \mu \mathrm{m}$. No cracks were noticed throughout the film. SEM micrograph as shown in Figure 5(b) represents to indium thin films annealed at $300^{\circ} \mathrm{C}$ for $4 \mathrm{hrs}$. From the image it is observed that growth in particle size has taken place along with the recrystallization phenomenon noticed on the surface of bigger particles. Uniformity of the film is still maintained. Most of the particles are found to be bigger than $1 \mu \mathrm{m}$. Crystallite size of the films annealed at $500^{\circ} \mathrm{C}$ was found to be further increased up to $2 \mu \mathrm{m}$ as compared to that of the films annealed at $300^{\circ} \mathrm{C}$. However the recrystallization phenomenon was maintained. Annealing at higher $700^{\circ} \mathrm{C}$ for $4 \mathrm{hr}$ temperature leads towards the diffusion of particles because of gaining thermal energy. A uniform matrix

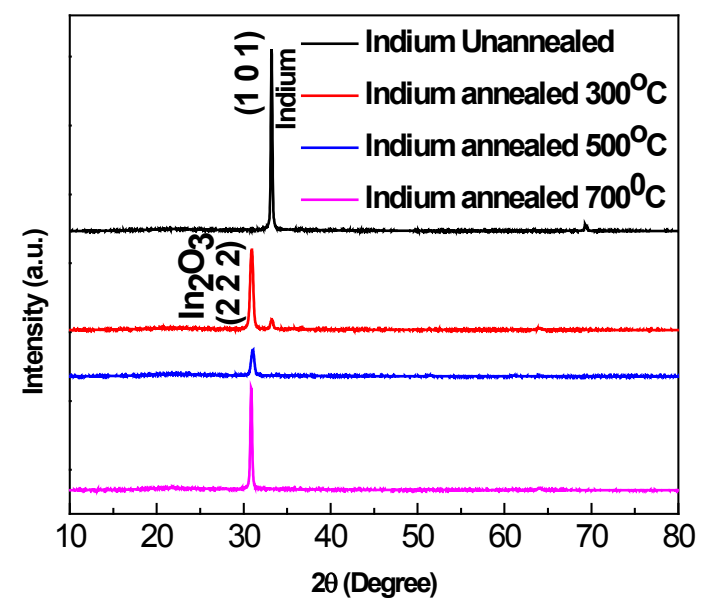

(e)

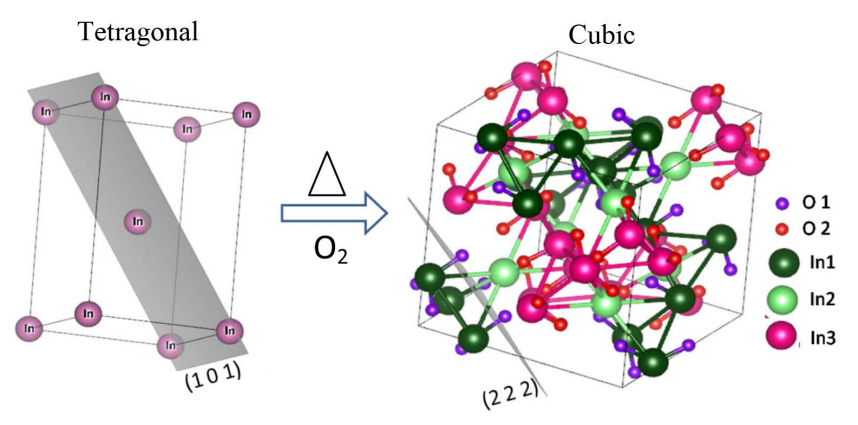

(f)

Figure 3. (e) XRD of indium oxide thin films deposited on quartz substrates annealed on 300,500 and $700^{\circ} \mathrm{C}$ for $4 \mathrm{hr}$; (f) A schematic of tetragonal and cubic unit cells as per the respective dimensional proportionate of indium and indium oxide. 

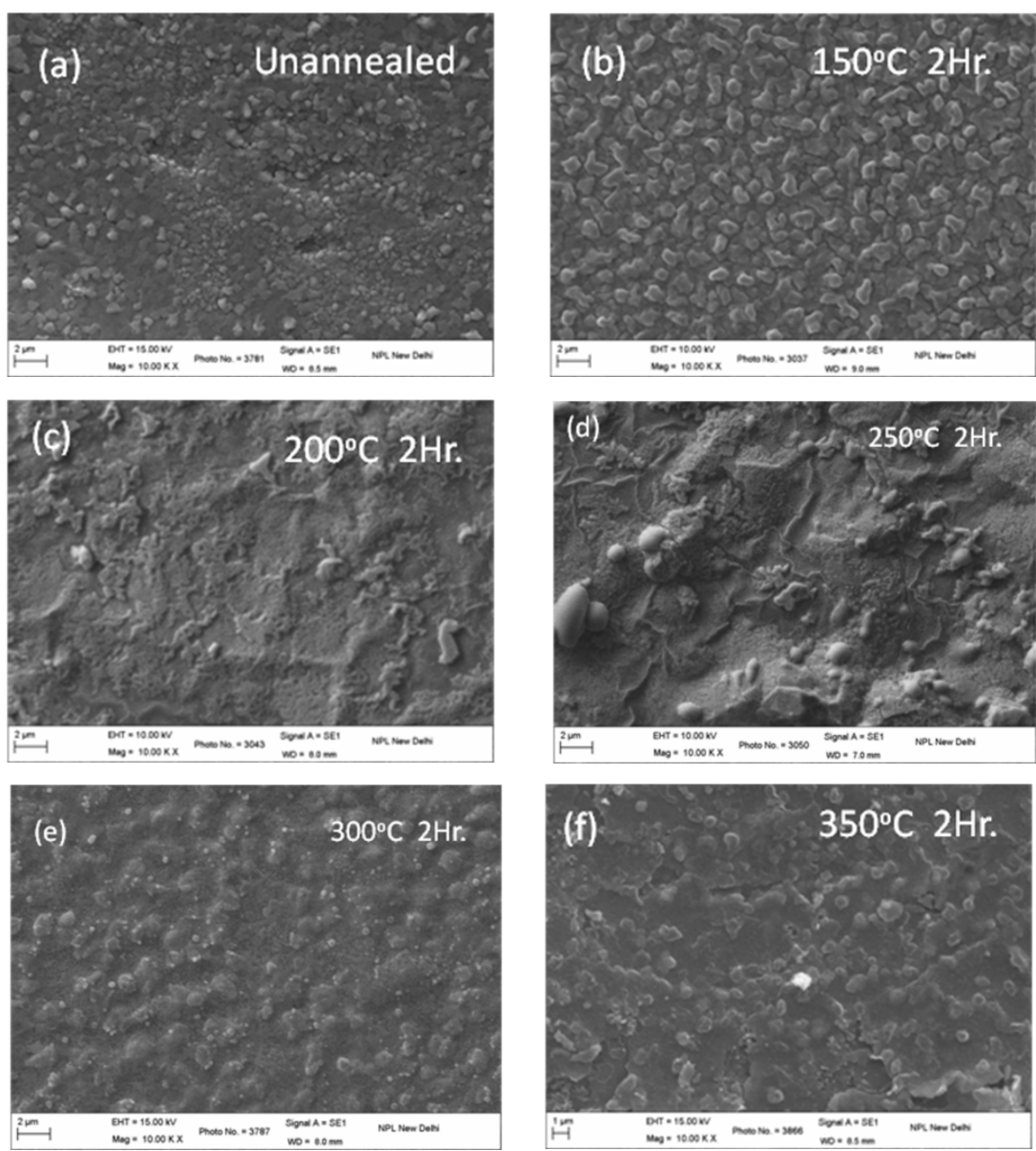

Figure 4. SEM micrographs of indium film as deposited, annealed at $150^{\circ} \mathrm{C}, 200^{\circ} \mathrm{C}$, $250^{\circ} \mathrm{C}, 300^{\circ} \mathrm{C}$ and $350^{\circ} \mathrm{C}$ for $2 \mathrm{hr}$ on glass substrate.
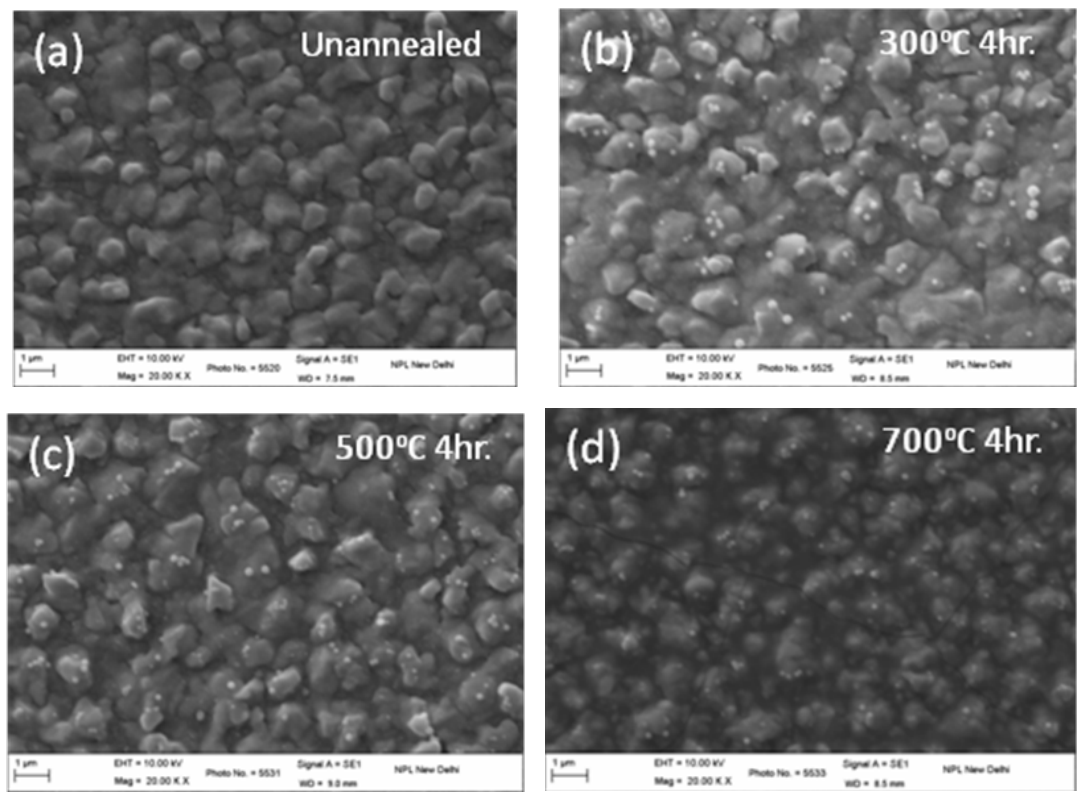

Figure 5. SEM micrographs of indium film deposited thin films on quartz substrate, annealed at $300^{\circ} \mathrm{C}, 500^{\circ} \mathrm{C}$ and $700^{\circ} \mathrm{C}$ for $4 \mathrm{hr}$. 
is formed after annealing at $700^{\circ} \mathrm{C}$ for $4 \mathrm{hr}$. and the growth of the particles have taken place along the direction of electron beam. It is important to be mention here that when films were annealed at $350^{\circ} \mathrm{C}$ for $2 \mathrm{hr}$ on glass substrate, there were some cracks in the films because of thermal stress developed due to difference in the linear thermal coefficient of the film and the substrate. However no such phenomenon was noticed in films annealed at $700^{\circ} \mathrm{C}$ on quartz substrate. Thus we conclude that films are seen to be more uniform on quartz substrate even at high temperature.

Microstructural features associated with Indium thin film deposited in the vacuum of the order of $10^{-6} \mathrm{mbar}$ recorded under TEM is shown in Figure 6(a). From the TEM micrograph, it is observed that the as deposited film consists of overlapped particles of size $30-60 \mathrm{~nm}$ having polyhedral shape. Small particles of size about $10 \mathrm{~nm}$ are also embedding between these comparatively big particles. Figure 6(b) shows the image of indium oxide after annealing at $300^{\circ} \mathrm{C}$ for $2 \mathrm{hr}$ in the presence of oxygen. The indium oxide particles rearrange themselves after recrystallization. Particle size is around $15 \mathrm{~nm}$ in the film. Further annealing of thin film at $350^{\circ} \mathrm{C}$ (Figure 6(c)) produces the stress in thin film and non uniformity is also depicted in the micrograph.

Atomic Force Microscope (AFM) is used for high resolution surface morphology in tapping mode for characterizing the indium oxide thin films. After analyzing the AFM images of indium oxide as deposited, $150^{\circ} \mathrm{C}$, $300^{\circ} \mathrm{C}$ and $350^{\circ} \mathrm{C}$ for $2 \mathrm{hr}$ show in Figures 7 (a)-(d), we observe that the particle size of as deposited film is around $500 \mathrm{~nm}$ and of irregular shape. The surface of thin film is rough and showing random distribution of particles. The results of AFM are in good agreement with SEM results. When thin films are annealed at $150^{\circ} \mathrm{C}$ for $2 \mathrm{hr}$ the size of particle gets large because of thermal energy supplied to the film.

Annealing at $300^{\circ} \mathrm{C}$ for $2 \mathrm{hr}$ leads towards the growth of indium oxide nano particles of about $50 \mathrm{~nm}$ due to recrystallization behavior but there are some unreacted indiums also present in the form of big particles in small quantity as compared to the small particles of indium oxide. Further annealing at $350^{\circ} \mathrm{C}$ for two hours converts all the indium particles into indium oxide of nano size of uniform distribution of particles. The roughness of the film is less compared to anneal at $300^{\circ} \mathrm{C}$.

The thin films are deposited on quartz substrates also and annealed at higher temperature for $4 \mathrm{hr}$ for observing the change in the properties of thin films and analyzed by AFM images in Figures 8(a)-(d). The observations of thin films as deposited, annealed at 300,500 and $700^{\circ} \mathrm{C}$ for $4 \mathrm{hrs}$ on quartz substrates is as follow. The particles in the as deposited thin films are of the size of $500 \mathrm{~nm}$ of the polyhedral shape. From the AFM images it also revealed the presence of some micro pores in the film.

As the annealing temperature is increased to $300^{\circ} \mathrm{C}$ particles are seen to grow in bigger size and the pores are found to be decreased suggesting the formation of more continuous film shown in Figure 8(b). With the further increase of annealing temperature at $500^{\circ} \mathrm{C}$, the particles of thin film are diffused to a greater extent with decrease in porosity as shown in Figure $8(\mathrm{c})$ and at $700^{\circ} \mathrm{C}$ the film looks completely uniform after diffusion of particles as shown in Figure 8(d).

\subsection{Optical Performance and Band-Energy Calculations}

Photoluminescence studies are done for the analysis of defects level present in the thin film. In the first experiment, we analyzed the photoluminescence spectra of indium oxide thin films annealed at $150^{\circ} \mathrm{C}, 200^{\circ} \mathrm{C}, 250^{\circ} \mathrm{C}$, $300^{\circ} \mathrm{C}$ and $350^{\circ} \mathrm{C}$ for $2 \mathrm{hr}$. on glass substrate as shown in Figure 9. From here we can see many peaks at varied

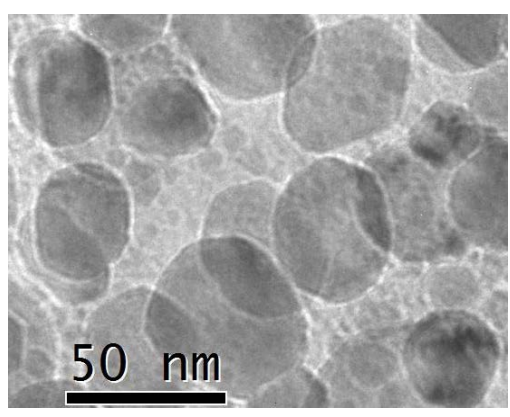

(a)

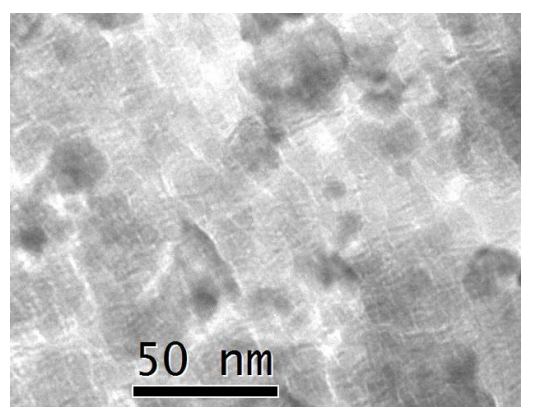

(b)

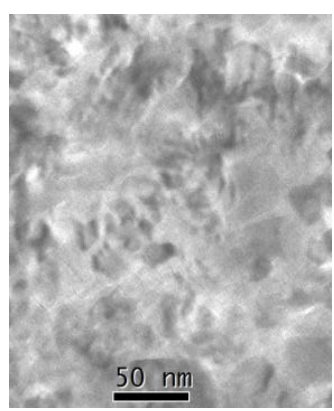

(c)

Figure 6. TEM images of indium film as deposited, and annealed at $300^{\circ} \mathrm{C}$ and $350^{\circ} \mathrm{C}$ for $2 \mathrm{hr}$ : (a) As deposited; (b) $300^{\circ} \mathrm{C}$; (c) $350^{\circ} \mathrm{C}$. 

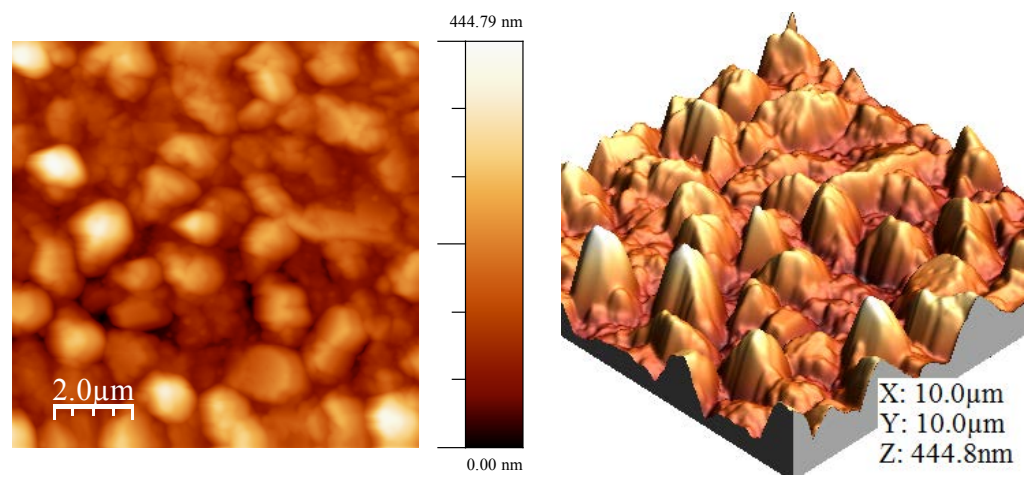

(a)
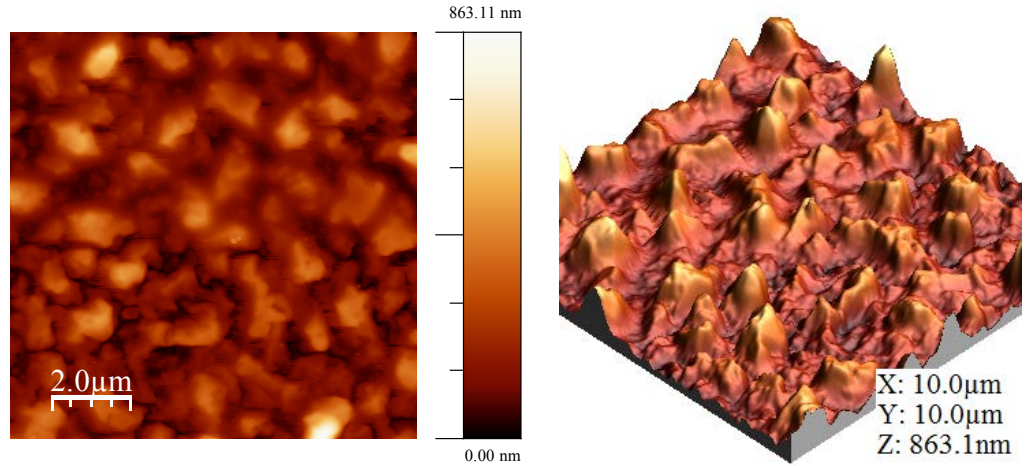

(b)
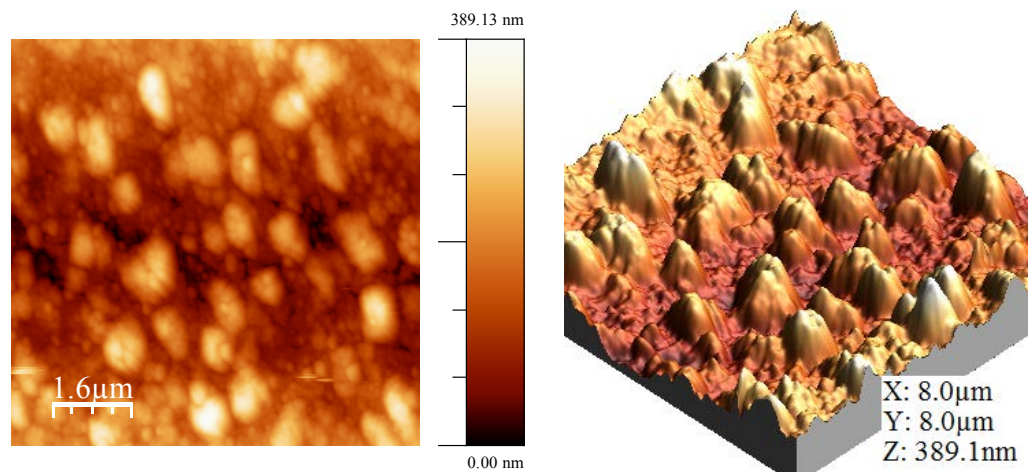

(c)
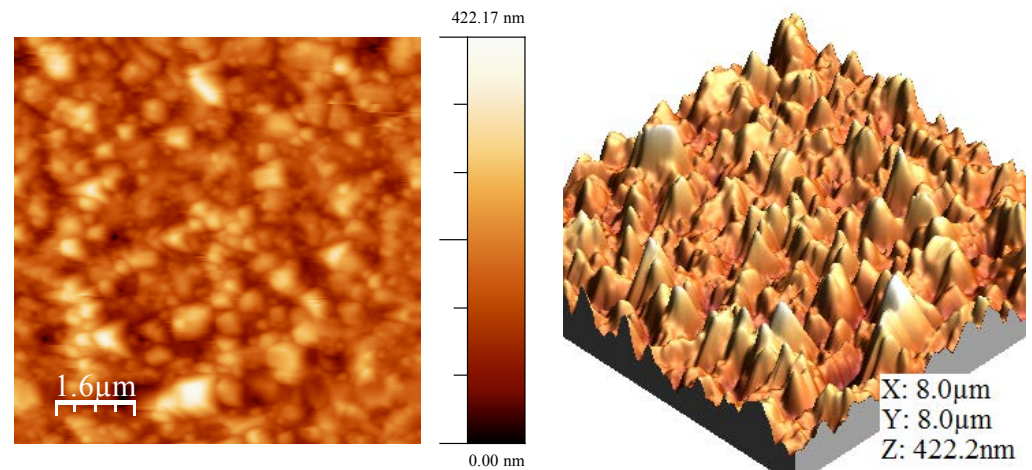

(d)

Figure 7. (a) AFM images of as deposited indium film, annealed at (b) $150^{\circ} \mathrm{C}$, (c) $300^{\circ} \mathrm{C}$ and (d) $350^{\circ} \mathrm{C}$ for $2 \mathrm{hr}$ on glass substrate 

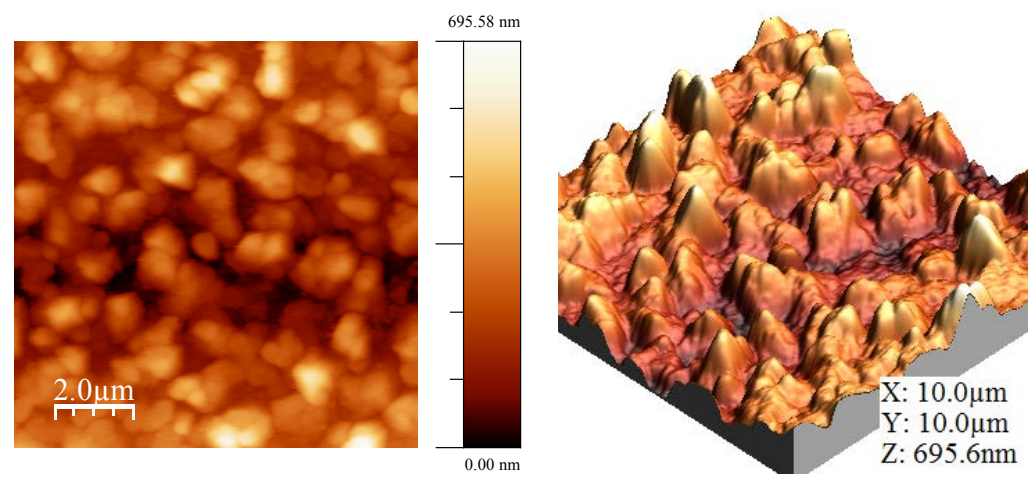

(a)
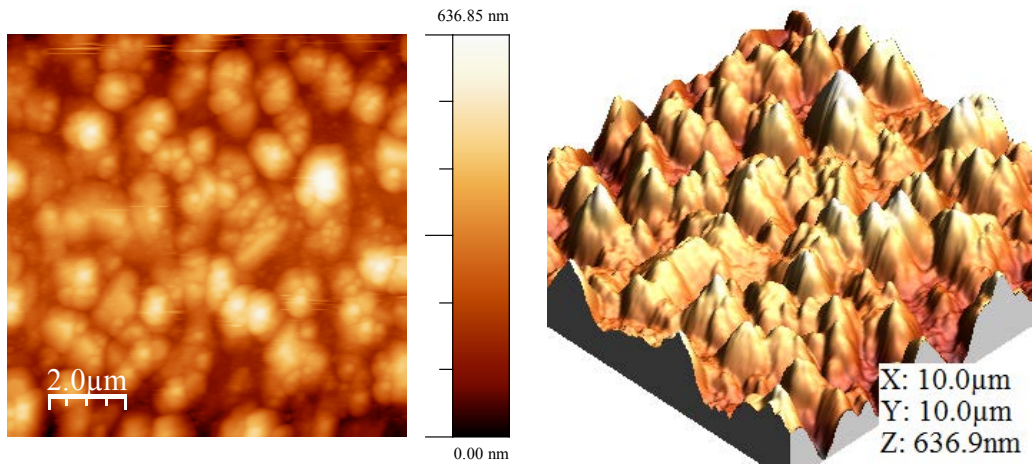

(b)
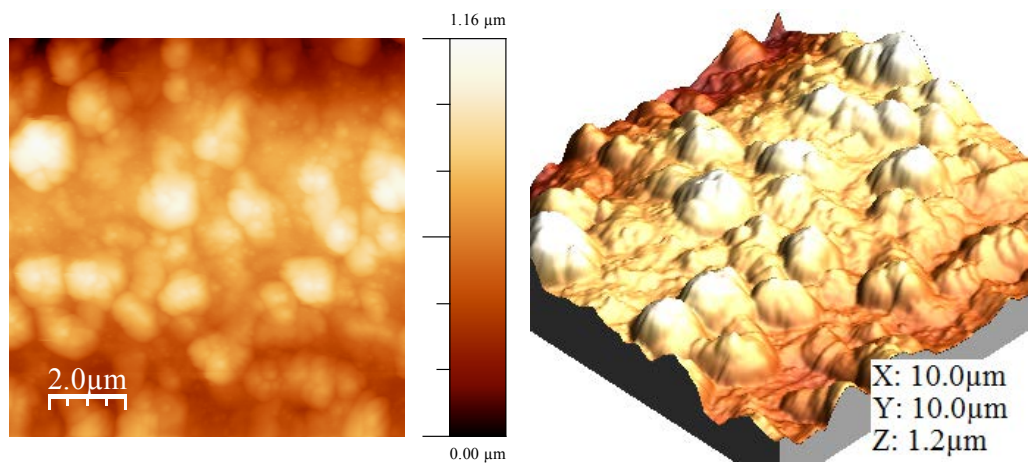

(c)
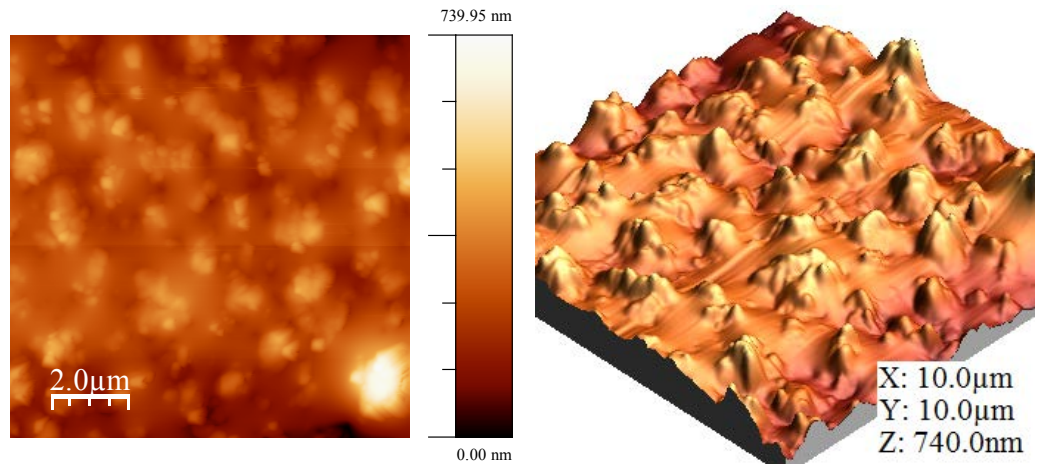

(d)

Figure 8. (a) AFM images of as deposited indium film, annealed at (b) $300^{\circ} \mathrm{C}$, (c) $500^{\circ} \mathrm{C}$ and (d) $700^{\circ} \mathrm{C}$ for $4 \mathrm{hr}$ on quartz substrate. 


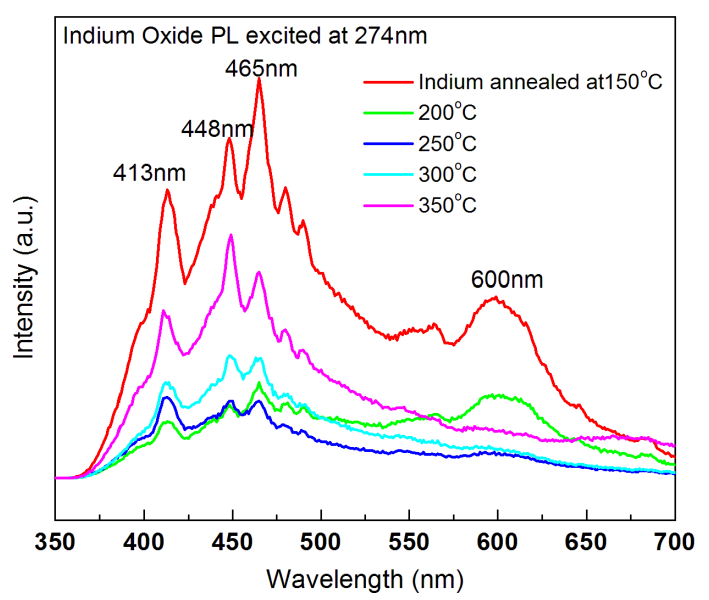

Figure 9. Photoluminescence spectra of indium oxide thin film annealed at $150^{\circ} \mathrm{C}, 200^{\circ} \mathrm{C}, 250^{\circ} \mathrm{C}, 300^{\circ} \mathrm{C}$ and $350^{\circ} \mathrm{C}$ for $2 \mathrm{hr}$ on glass substrate.

wavelength after exciting the thin film by the laser light having wavelength $274 \mathrm{~nm}$ in the PL spectrometer Perkin Elmer LS 55. The emission of light occurred at $413 \mathrm{~nm}, 448 \mathrm{~nm}, 465 \mathrm{~nm}$ and $600 \mathrm{~nm}$. These peaks are because of the band gap and some defects in the thin films. The emission peak around $600 \mathrm{~nm}$ is because of deficiency of oxygen in the indium oxide molecules. There is a change in the intensity of emission peaks because of particle distribution and number of defects but the change is not in regular manner.

The optical band gap can be estimated using the formula $E_{g}(\mathrm{eV})=1241 / \lambda(\mathrm{nm})$. The band gap calculated the indium oxide thin film is $2.66 \mathrm{eV}$ corresponding to the peak of wavelength $465 \mathrm{~nm}$.

Figure 10 shows the photoluminescence spectra of indium oxide thin film annealed at $300^{\circ} \mathrm{C}, 500^{\circ} \mathrm{C}$ and $700^{\circ} \mathrm{C}$ for $4 \mathrm{hr}$ on quartz substrate. The excitation wavelength is kept at $274 \mathrm{~nm}$. In the PL spectra, emission peaks are observed at $445 \mathrm{~nm}$. The intensity of the thin film annealed at $700^{\circ} \mathrm{C}$ is found to be highest as depicted in the figure. As deposited thin film does not show any emission peak while thin films annealed at $300^{\circ} \mathrm{C}$ to $700^{\circ} \mathrm{C}$ show the emission peaks at wavelength $445 \mathrm{~nm}$ and $485 \mathrm{~nm}$. The variation in the intensity of emission peaks as noticed may be due to the decrease in the defects in the thin films as the temperature of annealing is increased. The optical band gap calculated for these indium oxide thin films is $2.78 \mathrm{eV}$ corresponding to the peak of wavelength $445 \mathrm{~nm}$.

UV-visible spectroscopy is used for determining the transmittance of indium oxide thin films prepared at the annealing temperature of $300^{\circ} \mathrm{C}$ and $350^{\circ} \mathrm{C}$ for two hours in the presence of oxygen on glass substrate. The transmittance of film annealed at $300^{\circ} \mathrm{C}$ is about $74 \%$ as shown in Figure 11(a), whereas Figure 11 (b) shows that transmittance approximately $70 \%$ in case of film annealed at $350^{\circ} \mathrm{C}$ for $2 \mathrm{hr}$ on glass substrate. A Tauc plot is used to determine the direct optical band gap of thin films using the equation given below.

$$
h v \alpha(v)=B\left(h v-E_{g}\right)^{1 / 2}
$$

The variation of $(\alpha h v)^{2}$ with $h v$ is plotted and the linear portion of the plot is extrapolated to zero to find the band gap of the film (Figure 11 and Figure 12). From this equation we calculate that the direct optical band gap of thin films annealed at $300^{\circ} \mathrm{C}$ and $350^{\circ} \mathrm{C}$ for $2 \mathrm{hr}$ are found to be $3.91 \mathrm{eV}$ and $3.73 \mathrm{eV}$ respectively. The small variation in band gap thus observed may be due to the change in transmittance of the thin films.

It is further to be mentioned here that as we annealed these films at $300^{\circ} \mathrm{C}$ for $2 \mathrm{hr}$ and $4 \mathrm{hr}$, we observed that transmittance is more for film annealed for $4 \mathrm{hr}$ as compared to film annealed for $2 \mathrm{hr}$. The transparency is $83 \%$ for film annealed for $4 \mathrm{hr}$ and $74 \%$ for the film annealed for $2 \mathrm{hr}$ but there is a lowering of optical bad gap noticed because of increase in crystallinity of these film for long period annealing.

Similar annealing process was carried out on the thin films deposited on to quartz substrate. When we annealed these films at $300^{\circ} \mathrm{C}, 500^{\circ} \mathrm{C}$ and $700^{\circ} \mathrm{C}$ for $4 \mathrm{hr}$, the transparency is found to be decreased from $83 \%$ to $71 \%$ with the increase of annealing temperature. Table 2 shows the comparison between transmittance and optical band gap of the thin films prepared by annealing at different conditions.

As we observed in Figure 10, Photoluminescence spectra of indium oxide thin film annealed at $300^{\circ} \mathrm{C}, 500^{\circ} \mathrm{C}$ 


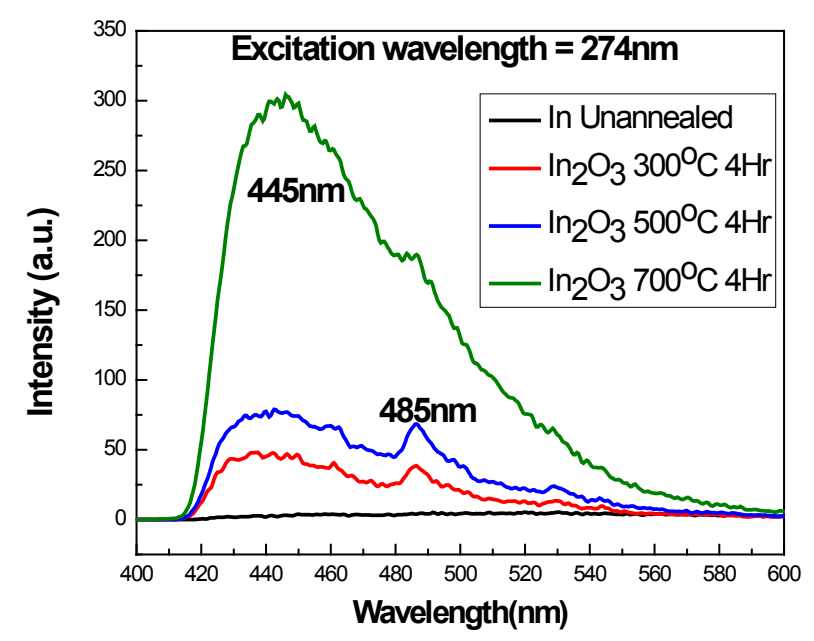

Figure 10. Photoluminescence spectra of indium oxide thin film annealed at $300^{\circ} \mathrm{C}, 500^{\circ} \mathrm{C}$ and $700^{\circ} \mathrm{C}$ for $4 \mathrm{hr}$ on quartz substrate.

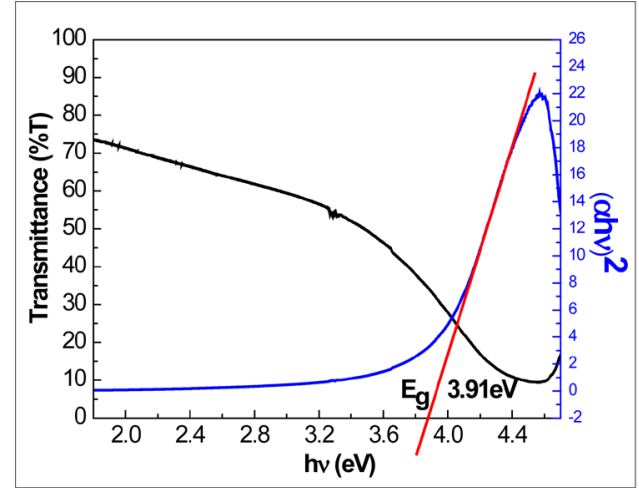

(a)

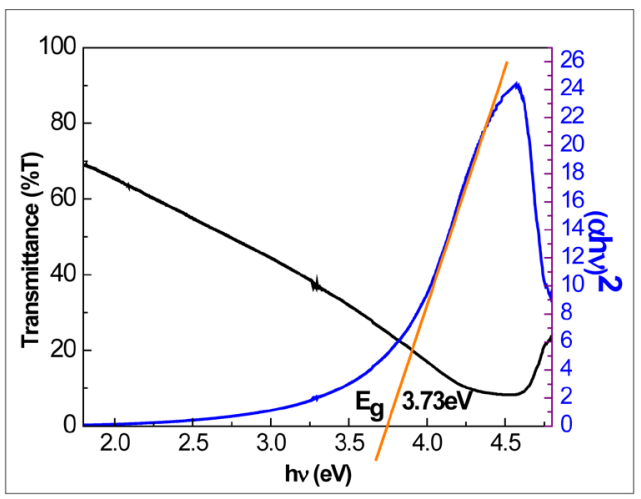

(b)

Figure 11. Transmission and absorption spectra of indium oxide thin film annealed at (a) $300^{\circ} \mathrm{C}$ and (b) $350^{\circ} \mathrm{C}$ for $2 \mathrm{hr}$ on glass substrate.

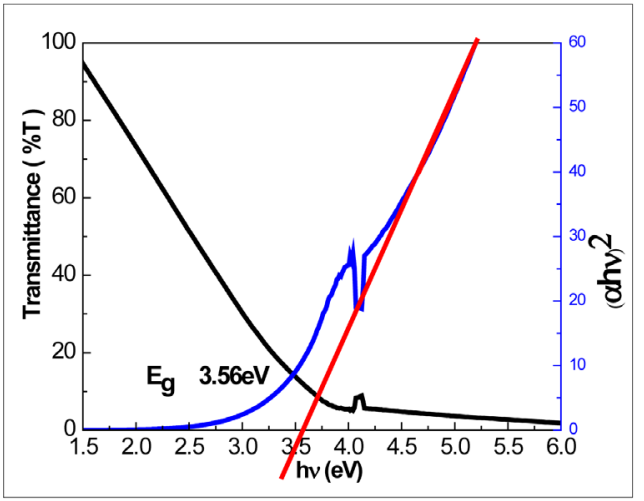

(a)

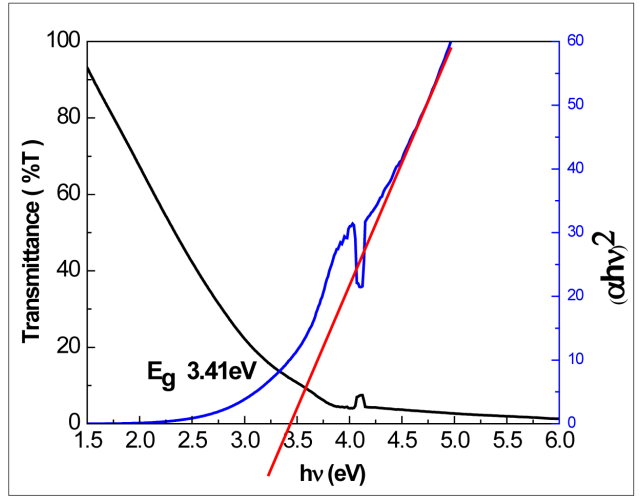

(b)

Figure 12. Transmission and absorption spectra of indium oxide thin film annealed at (a) $300^{\circ} \mathrm{C}$, (b) $500^{\circ} \mathrm{C}$ and (c) $700^{\circ} \mathrm{C}$ for $4 \mathrm{hr}$ on quartz substrate.

and $700^{\circ} \mathrm{C}$ for $4 \mathrm{hr}$ deposited on quartz substrate, the intensity of emission peaks is increasing with the increase of annealing temperature. The increase in the intensity of emission peak is due to more absorbance of excited light incident on the thin films. 
Table 2. Comparision of transmittance and direct optical band gap.

\begin{tabular}{ccccc}
\hline S. No. & Temperature $\left({ }^{\circ} \mathbf{C}\right)$ & Time (Hours) & Transmittance (\% T) & Band Gap (eV) \\
\hline 1. & 300 (glass) & 2 & 74 & 3.91 \\
2. & 350 (glass) & 2 & 70 & 3.73 \\
3. & 300 (quartz) & 4 & 83 & 3.56 \\
4. & 500 (quartz) & 4 & 80 & 3.41 \\
5. & 700 (quartz) & 4 & 71 & 3.66 \\
\hline
\end{tabular}

Table 3. Comparison of maximum response of Indium oxide thin films deposited at $300^{\circ} \mathrm{C}, 500^{\circ} \mathrm{C}$ and $700^{\circ} \mathrm{C}$ in the exposure of methanol, ethanol vapors and LPG.

\begin{tabular}{cccc}
\hline Sample & $\mathbf{3 0 0}^{\circ} \mathbf{C}$ & $\mathbf{5 0 0}^{\circ} \mathbf{C}$ & $\mathbf{7 0 0}^{\circ} \mathbf{C}$ \\
\hline Methanol response & 0.92 & 3.00 & 1.04 \\
Ethanol response & 1.13 & 3.55 & 1.73 \\
LPG response & 0.47 & 1.50 & 0.89 \\
\hline
\end{tabular}

\subsection{Electrical Response Measurement}

Thin films annealed at $300^{\circ} \mathrm{C}, 500^{\circ} \mathrm{C}$ and $700^{\circ} \mathrm{C}$ on quartz substrates were tested for their electrical response on exposure to ethanol, methanol and LPG. Electrical response was quantified as the drop in electrical resistance of the sensing film between the two electrodes. An indigenously developed setup was used for this characterization as shown in Figure 13. A gas chamber with inlet and outlet is used to measure the gas-sensing response of the sensors. Once the resistance stabilizes, the chamber is flushed with dry air. Gases are injected using a $1 \mathrm{ml}$ syringe. After injecting the gas into the chamber, the drop in resistance of the sample is measured and plotted by USBDAQ 0816 data logger (Hytek Automation Pvt. Ltd.) via an indigenously developed computer program. The variations in sensitivity of the gas sensors were studied at $500 \mathrm{ppm}$ and $100 \mathrm{ppm}$ gas concentration for ethanol and methanol and at $5000 \mathrm{ppm}$ and $1000 \mathrm{ppm}$ for commercial LPG at $573 \mathrm{~K}$ operating temperatures.

The gas sensing properties are characterized in term of dynamic change of resistance and gas-sensing response. The gas sensing response of n-type semiconductor based conductometric gas sensor to a reducing gas is normally defined as the ratio,

$$
\text { Response }=\frac{R_{\mathrm{air}}-R_{\mathrm{gas}}}{R_{\mathrm{gas}}}
$$

where,

$R_{\text {air }}=$ resistance of thin film in air;

$R_{\text {gas }}=$ resistance of thin film on exposure to ethanol or methanol or LPG vapors;

while the response to an oxidizing gas is defined as the ratio, $\Delta R / R_{\text {air. }}$. For p-type semiconductor gas sensor, the definitions are reversed. The gas-sensing response was calculated from dynamic variation of the conductance due to gas pulses introduction and plotted versus various parameters including temperature and gas concentration.

Figure 14 illustrates the dynamic response to ethanol, methanol and LPG of $\operatorname{In}_{2} \mathrm{O}_{3}$ thin films deposited at $300^{\circ} \mathrm{C}, 500^{\circ} \mathrm{C}$ and $700^{\circ} \mathrm{C}$. It can be seen that the resistances of the indium oxide thin films are reduced upon the exposure to reducing gas, indicating the n-type semiconductor behavior. The response is maximum for indium oxide thin films annealed at $500^{\circ} \mathrm{C}$ among all thin films. While each film shows maximum response towards ethanol vapors. The response for ethanol exposure to indium oxide thin films annealed at $500^{\circ} \mathrm{C}$ is 3.55 .

Figure 14 is showing another important factor for every gas sensor is its response and recovery times, when the sensor is exposed to and then removed from the gas environment. Here, the response time required for the response value to attain $90 \%$ of its maximum value is shorter $(\sim 20 \mathrm{sec})$ for indium oxide thin film. As the gas was turned-off, the response of the same film fell rapidly, indicating that the good recovery of the resistance was obtained. The time taken by the sensor elements to come back once the gas was removed is found $\sim 100 \mathrm{sec}$. 


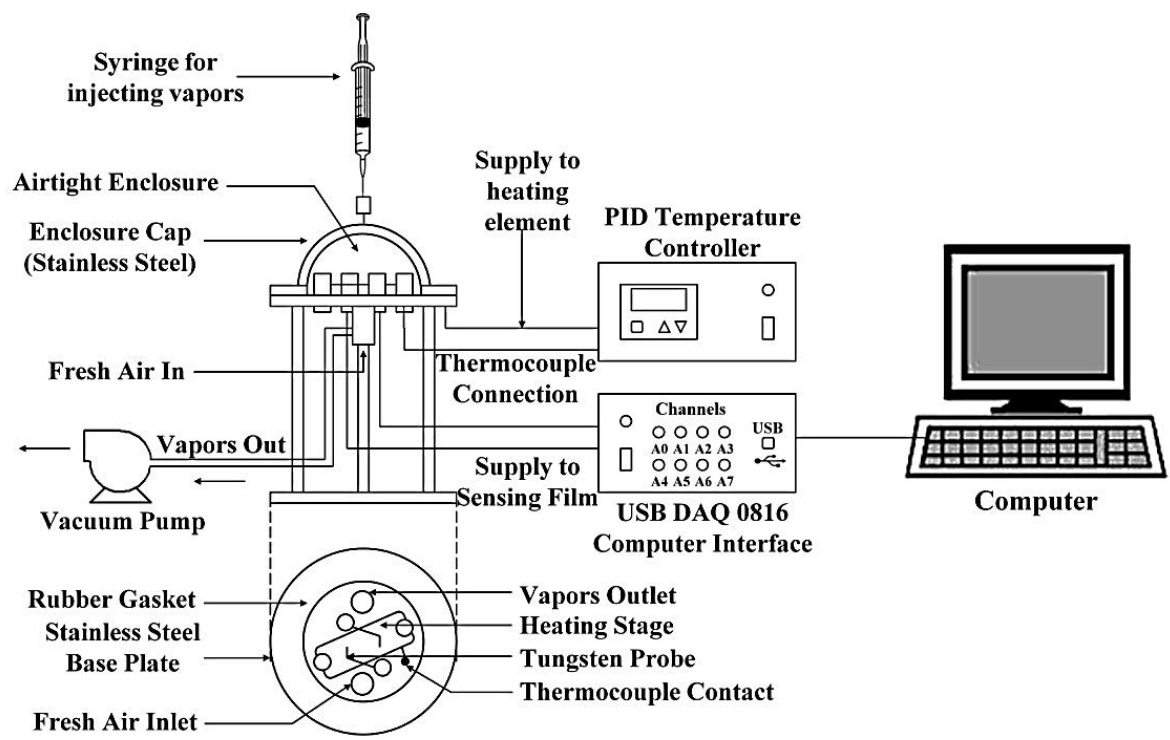

Figure 13. Indigenously developed semi-automated setup for electrical response measurement of sensing films. The system plots a real-time curve of resistance vs. time on the computer screen.
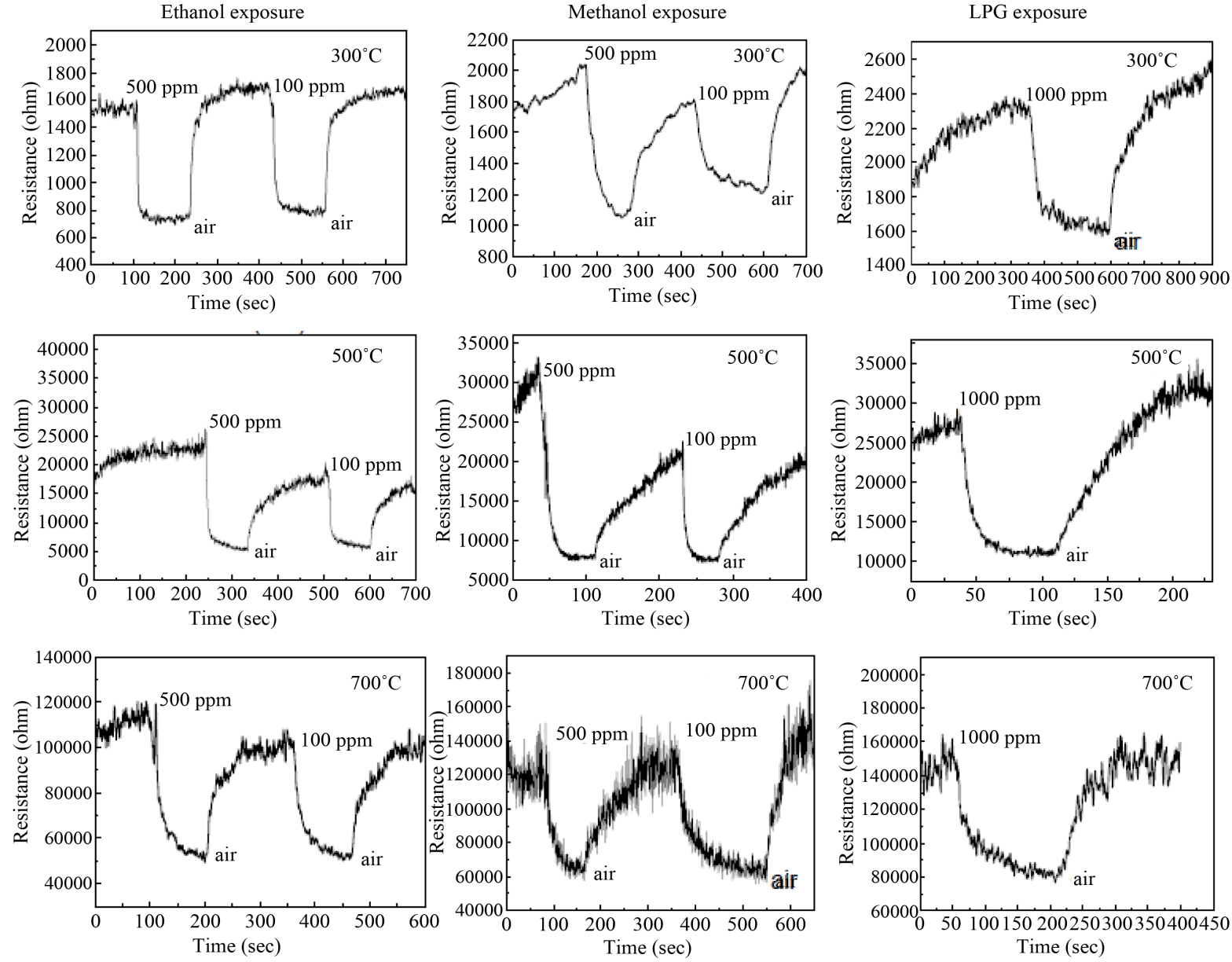

Figure 14. The dynamic response to ethanol, methanol and LPG of $\operatorname{In}_{2} \mathrm{O}_{3}$ thin films deposited at $300^{\circ} \mathrm{C}, 500^{\circ} \mathrm{C}$ and $700^{\circ} \mathrm{C}$. 
It is well known that the sensitivity of the indium oxide semiconductor sensors is mainly resolute by the interactions between the gas and the surface of the sensor. So, it is obvious that for the greater specific surface area of the materials, the interaction between the adsorbed gases and the sensor surface will be stronger, i.e. sensitivity will be higher. The gas sensing properties of materials are relative to the surface of the materials. The gases are always adsorbed and even react with the surface. So, small particle size and large specific area contribute to oxygen and gas adsorption on the surface of the materials, which is responsible for the increase in sensitivity of the sensor.

The electrical conductivity in indium oxide is due to non-stoichiometric composition as a result of oxygen deficiency (Figure 9 shows the oxygen deficiency obtained in PL spectra at $600 \mathrm{~nm}$ ). The conductivity is of n-type. When the indium oxide sensor surface is placed in an air ambient, the oxygen molecules are adsorbed at the surface resulting in the formation of $\mathrm{O}_{2}^{-}, \mathrm{O}^{-}$and $\mathrm{O}^{2-}$ ions, thus decreasing the concentration of the number of charge carriers near the surface giving rise to a depletion region. When exposed to reducing gases like methanol and ethanol vapour, mutual interaction between the reactant, i.e. reducing gas and oxygen species, results in oxidation of reducing gas at the surface. This oxidation phenomenon helps in the removal of oxygen ion from indium oxide surface resulting in decrease in the barrier height, thus increasing the conductance.

\section{Conclusion}

Indium oxide thin films synthesized by vacuum evaporation technique and further annealed at different temperatures for different duration under the oxygen atmosphere have revealed very interesting information. It is observed that annealing under oxygen atmosphere has resulted in formation of good quality single phase $\operatorname{In}_{2} \mathrm{O}_{3}$ thin films. Detailed analysis of XRD, SEM, AFM, photoluminescence spectra, and UV-visible exhibit that single phase indium oxide is formed at annealing over $300^{\circ} \mathrm{C}$ in the presence of oxygen. With the increase of annealing temperature, the growth in a particular direction takes place. The use of quartz substrate plays an important role in the stability of thin film. The transparency of thin films obtained by the present process is about $83 \%$. The direct optical band gap is $3.7 \mathrm{eV}$ which is close to the bulk indium oxide. By employing these experiments, we are able to synthesis the single phase indium oxide thin film. The sensing properties were also studied at low concentrations of ethanol, methanol and LPG. The response time is also fast. The results obtained by thermal evaporation technique are promising for the preparation of sensitive and low cost gas sensor operating at low temperatures. By adding different dopants to the parent material, the sensitivity of indium oxide film can be increased.

\section{Acknowledgements}

Mr. Parveen Jain thanks Council of Scientific and Industrial Research (CSIR-India) for providing the fellowship under which this research work is being carried out. We would also like to thank Director, NPL India for providing the necessary experimental facilities to carry out our research work. We also want to acknowledge the Dr. Divi Harnath for helping in the recording of photoluminescence spectra. We also want to acknowledge Sh. Vipin Singhal for arranging the gas sensing setup in the laboratory.

\section{References}

[1] Beena, D., Lethy, K.J., Vinodkumar, R., Detty A.P., Mahadevanpillai, V.P. and Ganesan, V. (2011) Photoluminescence in Laser Ablated Nanostructured Indium Oxide Thin Films. Journal of Optoelectronics and Advanced Materials, $\mathbf{5}, 1-11$.

[2] Wang, C.Y., Cimalla, V., Kups, T., Rohlig, C.C., Stauden, T., Ambacher, O., Kunzer, M., Passow, T., Schirmacher, W., Pletschen W. and Kohler, K. (2007) Integration of $\operatorname{~}_{2} \mathrm{O}_{3}$ Nanoparticle Based Ozone Sensors with GaInN/GaN Light Emitting Diodes. Applied Physics Letters, 91, Article ID: 103509. http://dx.doi.org/10.1063/1.2779971

[3] Harvey, S.P., Mason, T.O., Gassenbauer, Y., Schafranek, R. and Klein, A. (2006) Surface versus Bulk Electronic/Defect Structures of Transparent Conducting Oxides: I. Indium Oxide and ITO. Journal of Physics D: Applied Physics, 39, 3959-3968. http://dx.doi.org/10.1088/0022-3727/39/18/006

[4] Hotovy, I., Kups, T., Hotovy, J., Liday, J., Buc, D. and Caplovicova, M. (2010) Structural Evolution of Sputtered Indium Oxide Thin Films. Journal of Electrical Engineering, 61, 382-385.

[5] Huang, M.H., Wu, Y., Feick, H., Tran, N., Weber, E. and Yang, P.(2001) Catalytic Growth of Zinc Oxide Nanowires by Vapor Transport. Advanced Materials, 13, 113-116. http://dx.doi.org/10.1002/1521-4095(200101)13:2<113::AID-ADMA113>3.0.CO;2-H 
[6] Gu, F., Wang, S.F., Lu, M.K., Cheng, X.F., Liu, S.W., Zhou, G.J., Xu, D. and Yuan, D.R. (2004) Luminescence of $\mathrm{SnO}_{2}$ Thin Films Prepared by Spin-Coating Method. Journal of Crystal Growth, 262, 182-185. http://dx.doi.org/10.1016/j.jcrysgro.2003.10.028

[7] Pramod, N.G., Pandey, S.N. and Sahay, P.P. (2012) Structural, Optical and Methanol Sensing Properties of Sprayed $\mathrm{In}_{2} \mathrm{O}_{3}$ Nanoparticle Thin Films. Ceramics International, 38, 4151-4158. http://dx.doi.org/10.1016/i.ceramint.2012.01.075

[8] Guha, P., Kar, S. and Chaudhuri, S. (2004) Direct Synthesis of Single Crystalline $\mathrm{In}_{2} \mathrm{O}_{3}$ Nanopyramids and Nanocolumns and Their Photoluminescence Properties. Applied Physics Letters, 85, 3851-3853. http://dx.doi.org/10.1063/1.1808886

[9] Jia, H.B., Zhang, Y., Chen, X.H., Shu, J., Luo, X.H., Zhang, Z.S. and Yu, D.P. (2003) Efficient Field Emission from Single Crystalline Indium Oxide Pyramids. Applied Physics Letters, 82, 4146-4148. http://dx.doi.org/10.1063/1.1582354

[10] Li, S.Q., Liang, Y.X. and Wang, T.H. (2005) Electric-Field-Aligned Vertical Growth and Field Emission Properties of $\mathrm{In}_{2} \mathrm{O}_{3}$ Nanowires. Applied Physics Letters, 87, Article ID: 143104. http://dx.doi.org/10.1063/1.2076438

[11] Jeong, J.S., Lee, J.Y., Lee, C.J., An, S.J. and Yi, G.C. (2004) Synthesis and Characterization of High-Quality $\mathrm{In}_{2} \mathrm{O}_{3}$ Nanobelts via Catalyst-Free Growth Using a Simple Physical Vapor Deposition at Low Temperature. Chemical Physics Letters, 384, 246-250. http://dx.doi.org/10.1016/j.cplett.2003.12.027

[12] Wu, X.C., Hong, J.M., Han, Z.J. and Tao, Y.R. (2003) Fabrication and Photoluminescence Characteristics of Single Crystalline $\mathrm{In}_{2} \mathrm{O}_{3}$ Nanowires. Chemical Physics Letters, 373, 28-32. http://dx.doi.org/10.1016/S0009-2614(03)00582-7 